\title{
Evaluation of Groundwater Quality Index for drinking purpose from some villages around Darbandikhan district, Kurdistan Region -Iraq
}

\author{
Ali Bawasheakh Ahmad \\ Assistant Lecturer in Soil and Water Science Department, Faculty of Agriculture Sciences, University of \\ Sulaimani, Sulaimani City,
}

\begin{abstract}
This study was conducted over seven villages near Darbandikhan district including (2) wells and (5) springs. It covers more than $60 \mathrm{~km}^{2}$, to assess the suitability of ground water quality for drinking purpose using water quality index through investigating of different wells and springs; this technique is very useful tool for quick assessment for any water system. This was done by subjecting the seven water resources in the mentioned area under investigation, where drinking water samples are not treated before consumption. For calculating Water Quality Index, fourteen parameters such as $\left(\mathrm{pH}, \mathrm{TDS}\right.$, EC, Turbidity, Total Hardness as $\mathrm{CaCO}_{3}$, Calcium, Magnesium, Sulphate, Chloride, Nitrate $\left(\mathrm{NO}_{3}-\mathrm{N}\right)$, Nitrite $\left(\mathrm{NO}_{2}-\mathrm{N}\right)$, Phosphate $\left(\mathrm{PO}_{4}-\mathrm{P}\right)$, Sodium and Potassium) have been considered. The study spread over two seasons namely fall and spring. The observed values of these physicochemical parameters were compared with World Health Organization standards. The results indicated that water quality of springs and wells varied from excellent water quality (A) to good water quality (B).
\end{abstract}

Key words: Water Quality Index, Assessment, Physical-chemical Parameters, Suitability for Drinking, Ground Water.

\section{Introduction}

Water quality index (WQI) is valuable and unique rating to depict the overall water quality status in a single term that is helpful for selecting appropriate treatment technique to meet the concerned issues. Whereas, water quality index depicts the composite influence of different water quality parameters and communicates water quality information to the public and legislative decision makers. Recent research conducted by (Yisa and Jimoh, 2010) showed that there was an increase in the demand for freshwater due to rapid population growth as well as the accelerated pace of industrialization in the last few decades. Ground water is a gift of nature, its quality about 210 billion $\mathrm{m}^{3}$ including recharge through infiltration seepage and evaporation. Ground water is the main source of drinking water. Today human activities are constantly adding industrial, domestic and agricultural waste to ground water reservoirs at an alarming rate (Panda and Sinha, 1991). With growing industrial sectors, urban areas also developed near the industrial areas. So, the consumption of fresh water is increased also. Disposal of industrial effluent and sewage into fresh water cause ground water pollution (Panigrahi et al., 2012). The quality of ground water may also vary with depth of water table, seasonal changes and composition of dissolved salts depending upon sources of the salt and sub surface environment (Gebrehiwot et al., 2011). The present study focus on the water qualities of some villages near Darbandikhan district. The physicochemical properties of springs and wells were determined and compared with international of WHO together with recommended water guidelines for drinking water and domestic uses based on water quality index. This was derived by weighted arithmetic method. It is one of the most effective ways to communicate information on water quality trends to policy makers to shape strong public policy and implement the water quality programs (Kalavathy et at., 2011). The WQI was first developed by Horton in early 1970s based on weighted arithmetical calculation, a number of researchers all over the world developed WQI models based on weighing and rating of different water quality parameters (UNEP GEMS, 2007, Kavitha and Elangovan, 2010 and Alobaidy et al., 2010). The water quality index is a dimensionless number with values ranking between 0 and 100. The higher index value represents a good water quality (Cude, 2001, Pandey and Sundaram, 2002). This numerical index can use as a management tool in water quality assessment. In Iraq, many researchers and projects have been conducted to measure surface water quality index but in Kurdistan region of Iraq, few studies have been done conducted on water quality index (Shekha, 2008) applied water quality index for both Erbil wastewater channel and great Zab river. (Alobaidy et al., 2010) formulated application of water quality index for assessment of Dokan Lake ecosystem. Determination of Water Quality Index for Qalyasan Stream in Sulaimani City (Khwakaram et al., 2012) and (HamaSalh, 2014) Water Quality Index (WQI) of some Wells located in the region of Kani Goma and Kanasura in Sulaimani governorate. Evaluation of ground water quality and its suitability for drinking is the objective of the present study by comparing the results against drinking water 
quality standards laid down by world Health organization. The suitability of ground water for domestic use has been based on water quality index.

\section{Materials And Methods}

Study area: Darbandikhan district is located at northeast of Iraq $531 \mathrm{~m}$ altitude and $65 \mathrm{~km}$ far from Sulaimani City. The ground water samples were collected from seven different villages (2) wells and (5) springs (Miradee, Ahmad brnda, China rah, Azaban, Siyara, Birke and Qashti) near Darbandikhan district, it is far about $15 \mathrm{~km}$ from the Darbandikhan and it is a rural area composed of 2000 residents which are the only main sources of water for the community. The study area is located in the northeast of Darbandikhan and it is under investigation lies approximately between North latitudes $35^{\circ} 08^{\prime} 73^{\prime \prime}$ to $35^{\circ} 14^{\prime} 27^{\prime \prime}$ and East longitudes $45^{\circ} 41^{\prime} 32^{\prime \prime}$ to $45^{\circ} 44^{\prime}$ 49" as show in Figure (1).

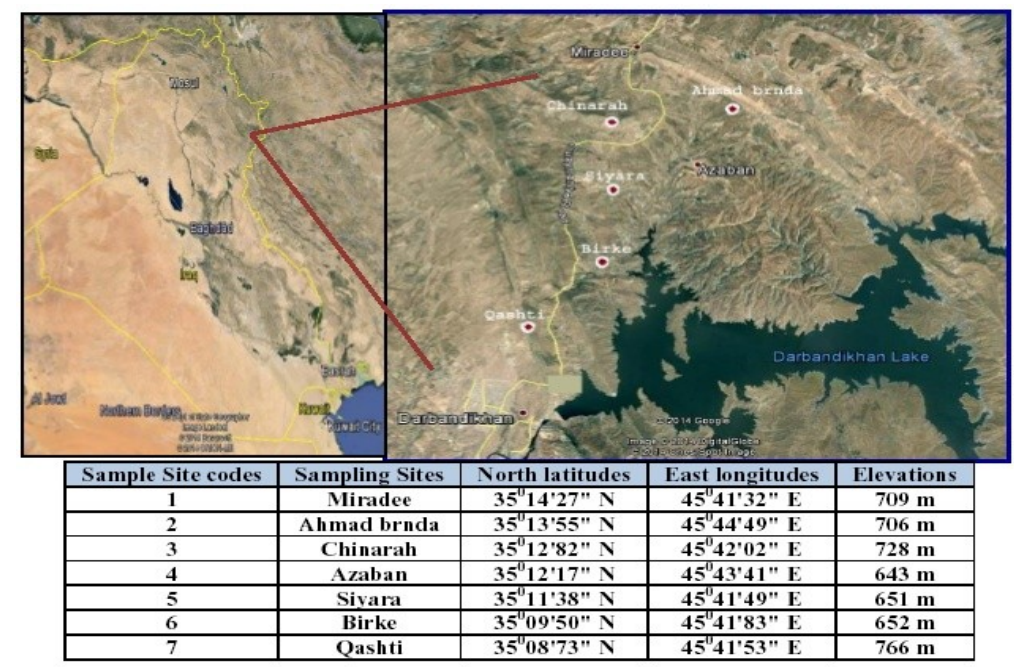

Figure 1: Satellite image of the study area showing the sampling sites according to Lat. N, Long. E and elevations

Analytical methods: Water samplings were done two times at two different sampling periods. Samples were collected in (November; 2013 and February; 2014) using acid washed 0.5 liter polypropylene (PET) bottles to avoid unpredictable changes in characteristic of water according to standard procedures (APHA et al., 1998). The physiochemical properties of water samples were determined and performed on the same day of sampling, and analyzed for 14 physicochemical parameters using following procedures. The water samples were analyzed for most parameters using a photo Lab spectral model (82362 Weilheim) WTW company-Germany according to (A.P.H.A., 1989), except $\mathrm{Na}^{+}$and $\mathrm{K}^{+}$which were determined using flame photometer model (JENWAY PF P7), as described in (A.P.H.A., 1989). The $\mathrm{pH}$, electrical conductivity (EC) and Turbidity were analyzed using $\mathrm{pH}-$ meter, model (Microprocessor pH meter, Hanna pH 211), according to (Jackson, 1958), a portable (EC) meter (LF318/SET, WTW Company-Germany), according to (Wilcox, 1950) and turbidity meter (Photo Flex/Photo Flex Turb.WTW Company-Germany), as recommended by (APHA et al., 1998) respectively.

\section{Calculation of Water Quality Index (WQI)}

The water quality index was calculated depending on fourteen parameters. The WQI has been calculated using the drinking water quality standard recommended by the World Health Organization (WHO, 2011). The weighted arithmetic index method (Brown, 1972) used for the calculating WQI of the water body in following steps:

\section{a. Calculation of Sub Index of Quality Rating $\left(q_{n}\right)$}

Let there be $\boldsymbol{n}$ water quality parameters, where the quality rating or sub index ( $\boldsymbol{q n})$ corresponding to the $\boldsymbol{n}^{\text {th }}$ parameters is a number reflecting the relative value of these parameters in the polluted water with respect to its standard permissible value. The value of $\boldsymbol{q}_{n}$ is calculated using the following expression.

$$
\begin{aligned}
& q_{n}=100\left[V_{n}-V_{i o}\right] /\left[S_{n}-V_{i o}\right] \\
& \text { Where, }
\end{aligned}
$$$$
\boldsymbol{q}_{\boldsymbol{n}}=\text { Quality rating for the } \boldsymbol{n}^{\text {th }} \text { water quality parameters }
$$$$
\boldsymbol{V}_{\boldsymbol{n}}=\text { Estimated value of the } \boldsymbol{n}^{\text {th }} \text { parameter at a given sampling station. }
$$$$
\boldsymbol{S}_{\boldsymbol{n}}=\text { Standard permissible value of the } \boldsymbol{n}^{\text {th }} \text { parameters }
$$

$\boldsymbol{V}_{\boldsymbol{i o}}=$ Ideal value of $\boldsymbol{n}^{\text {th }}$ parameter in pure water. (i.e., 0 for all other parameters except the parameter $\mathrm{pH}$ and dissolved oxygen (7.0 and $14.6 \mathrm{mg} \mathrm{l}^{-1}$ respectively) (Tripaty and Sahu, 2005). 


\section{b. Calculation of Quality Rating for $\mathrm{pH}$}

For $\mathrm{pH}$ the ideal value is 7.0 (for natural water) and a permissible value is 8.5 (for polluted water). Therefore, the quality rating for $\mathrm{pH}$ is calculated from the following relation:

$q_{p H}=100\left[\left(V_{p H}-\mathbf{7 . 0}\right) /(8.5-7.0)\right]$

Where,

$V_{p H}=$ observed value of $\mathrm{pH}$ during the study period.

If quality rating $q_{n}=0$ means complete absence of pollutants,

While $0<q_{n}<100$ implies that, the pollutants are within the prescribed standard.

When $q_{n}>100$ implies that, the pollutants are above the standards.

\section{c. Calculation of Unit Weight (Wn)}

Calculation of unit weight $(\boldsymbol{W n})$ for various water quality parameters are inversely proportional to the recommended standards value $\boldsymbol{S} \boldsymbol{n}$ of the corresponding parameters.

\section{$\boldsymbol{W n}=\mathbf{K} / \mathbf{S n}$

Where,

$\boldsymbol{W n}=$ Unit weight for the $\boldsymbol{n}^{\text {th }}$ parameters.

$\boldsymbol{S n}=$ Standard value for $\boldsymbol{n}^{\text {th }}$ parameters.

$\mathbf{K}=$ Proportional constant, this value considered (1) here, also can calculate using the following equation:

$K=1 / \Sigma(1 / S n)$ linearly.

The overall Water Quality Index was calculated by aggregating the quality rating with the unit weight

If water quality index (WQI) is less than 50 such water is slightly polluted and fit for human consumption, WQI between $(51-80)$ moderately polluted, WQI between $(50-100)$ excessively polluted and WQI-Severely polluted (Sinha et at., 2004).

$$
W Q I=\underset{n q n}{n} W n / \stackrel{n}{\sum} W n
$$

Table 1: Water Quality Index (WQI) and status of water quality

[Chaterjee and Raziuddin, 2002]

\begin{tabular}{|c|c|c|}
\hline Water Quality Index Level & Water quality status & Grading \\
\hline $0-25$ & Excellent water quality & A \\
\hline $26-50$ & Good water quality & B \\
\hline $51-75$ & Poor water quality & C \\
\hline $76-100$ & Very poor water quality & D \\
\hline$>100$ & Unsuitable for drinking & E \\
\hline
\end{tabular}

\section{Results And Discussion}

Water quality index of the ground water samples are established on important various physiochemical parameters for seven sites, from several villages around Darbandikhan district. Various physiochemical parameters were calculated for water quality index Table (2). The WQI for all the samples taken were calculated according to the procedure explained previously in materials and methods. WQI indicates the quality of water in terms of index number which represents overall quality of water for any intended uses. On the basis of the WQI, the water quality index obtained for ground water samples in different sites in (November; 2013 and February; $2014)$ are $32.82,13.51,18.86,24.43,13.42,11.77$ and 14.75 respectively Table $(3,4,5,6,7,8$ and 9$)$.

The WQI results obtained for the different sampling sites were found to fall under the class from excellent water quality (0-25) class at the sample sites (2-Ahmad brnda, 3-China rah, 4-Azaban, 5-Siyara, 6Birke and 7-Qashti) to Good water quality (25 - 50) class at the sample site (1-Miradee), Table (1). Those index values revealed that the status of the ground water samples were suitable for drinking at all sampling locations according to WHO guideline standards (WHO, 2011).

The $\mathrm{pH}$ of the aquatic systems is an important indicator for the water quality assessment and extent pollution in the watershed areas. Results obtained for $\mathrm{pH}$ varied between (7.23 and 7.68). The $\mathrm{pH}$ values of the studied waters were ranging between the minimum value of 7.23 at site (1) while, the maximum value was 7.68 at site (2) Table (2). $\mathrm{pH}$ measurement is very important as an indication of water quality due to the sensitivity of organisms to the $\mathrm{pH}$ of their environment. $\mathrm{pH}$ is also important in assessing the suitability of water for drinking (WHO, 2004). However, the $\mathrm{pH}$ concentration in the study area is within allowable standard permissible limits of (World Health Organization) (WHO, 2011).

The EC values for the investigated periods ranged between (342.50 to 796.50) $\mu \mathrm{S} \mathrm{cm}^{-1}$ at sites (2 and 7) respectively. Table (2) which were lower than the suggested level $\left(1500 \mu \mathrm{S} \mathrm{cm}^{-1}\right)$ by WHO (WHO, 2011). The results showed those waters were suitable for dinking depending on WHO (1000 $\left.\mathrm{mg} \mathrm{l}^{-1}\right)$. The TDS values 
ranged from the minimum value of TDS was $219.20 \mathrm{mg} \mathrm{l}^{-1}$ at site (2) and maximum value was $509.76 \mathrm{mg}^{-1}$ at site (7). Primary sources for TDS in receiving waters are agricultural and residential runoff, leaching of soil contamination and point source water pollution discharge from industrial or sewage treatment plants (Boyd, 2000). Turbidity is widely concerned as an important parameter for drinking water. However, the observed values were within permissible level recommended by WHO ( 5 NTU) for all sites. The minimum value $(<0.01$ NTU) recorded from sites $(2,5$, and 7$)$ and maximum value (4.94 NTU) recorded at site (1).

The result of Calcium was higher than the permissible level recommended by the WHO $\left(75 \mathrm{mg} \mathrm{l}^{-1}\right)$ for drinking water of all sites. The Calcium enters water by leaching from minerals within an aquifer. Common calcium-containing minerals are calcite and gypsum, also some human activities involved in increasing calcium concentration of carbon dioxide which form the carbonic acid that eventually lead to dissolve the bituminous lime rocks (Boyd, 2000). The concentrations of Magnesium in studied waters were ranged between (61.30 to 92.15) $\mathrm{mg} \mathrm{l}^{-1}$ at sites (1 and 7) respectively Table (2) and the result of Magnesium was lower than the permissible level recommended by WHO $\left(100 \mathrm{mg} \mathrm{l}^{-1}\right)$. Total Hardness varies from $(598.21$ to 760.17$) \mathrm{mg}^{-1}$ as $\mathrm{CaCO}_{3}$. The hardness values for the study waters are found to be high for all locations and determined to fall above the desirable limit of WHO specification $\left(500 \mathrm{mg}^{-1}\right)$. Total hardness mainly a reflect the major ions, e.g., $\mathrm{Ca}^{2+}, \mathrm{Mg}^{2+}, \mathrm{CO}_{3}{ }^{2-}$ and $\mathrm{HCO}_{3}^{-}$, being present in the water. These ions enter the ground water by leaching from minerals like Calcite, gypsum and Dolomite.

Chloride is one of the most important parameter in assessing water quality. In the present study the concentration of chloride fluctuated between $(19.50$ to 29.50$) \mathrm{mg} \mathrm{1^{-1 }}$. Thus the water for all study sites considered as fresh water because they were containing low levels of chloride, therefore it is within permissible level recommended by the WHO $\left(250 \mathrm{mg} \mathrm{l}^{-1}\right)$, for drinking water.

The sulfate concentrations of studied waters were ranged from (43 to131) $\mathrm{mg} \mathrm{l}^{-1}$. Generally, Iraqi Kurdistan region inland waters usually contain significant amount of sulfate. While the dissolution of gypsum from sedimentary rocks required a period of time for contacting with ground water, so shallow aquifers containing low concentration of sulfate (Rasheed, 1994), due to the rocks formation of the area is rich in gypsum. There for, their values were higher than in other parts of the world (WHO, 1996). These results are in agreement with those results of previous worker in Kurdistan (Zeywayee, 2011 and Ganjo, 1997). In this study, sulfate concentration values relatively were high but within the permissible level recommended by the WHO $\left(250 \mathrm{mg} \mathrm{l}^{-1}\right)$, for drinking water.

The phosphate values obtained were without the tolerable limits and within permissible limit $\left(5 \mathrm{mg}^{-1}\right)$. The minimum and maximum values were $(0.20$ and 0.45$) \mathrm{mg} \mathrm{l}^{-1}$ for sites (5 and 6) respectively, which suggest that phosphorus is rarely found in high concentrations in waters as it is actively taken up by plants. The values of sodium were found to be always higher than potassium and much less than that of calcium. The differences between sodium and potassium values at the waters possibly are related to the soil formation within the study area. The sodium and potassium concentrations were ranged (5.40 to 28.30 and 0.20 to 2.26$) \mathrm{mg}^{-1}$ were within permissible level recommended by WHO (250 and 12) $\mathrm{mg}^{-1}$ respectively, for drinking water.

Nitrate and Nitrite are naturally ions that are part of nitrogen cycle. Nitrate ion in water is undesirable. Because it causes methaemoglobinaemia in infants less than 6 months old (Egereonu and Nwachukwu, 2005), however, the nitrate value varies from (1.50-8.50) $\mathrm{mg} \mathrm{l}^{-1}$. Although all the samples exceed the permissible limit which could be due to leaching from waste disposal, sanitary landfills, over application of inorganic nitrate fertilizer or improper manure management practice (Chapman, 1996).

Table 2: The mean of physiochemical parameters for all studied groundwater sites.

\begin{tabular}{|c|c|c|c|c|c|c|c|}
\hline Sampling Sites & $\begin{array}{c}\text { Miradee } \\
\text { (dug well) }\end{array}$ & $\begin{array}{l}\text { Ahmad } \\
\text { brnda spring) }\end{array}$ & $\begin{array}{c}\text { Chinarah } \\
\text { ( dug well) }\end{array}$ & $\begin{array}{l}\text { Azaban } \\
\text { ( Spring) }\end{array}$ & $\begin{array}{c}\text { Siyara } \\
\text { ( Spring) }\end{array}$ & $\begin{array}{c}\text { Birke } \\
\text { ( Spring) }\end{array}$ & $\begin{array}{c}\text { Qashti } \\
\text { ( Spring) }\end{array}$ \\
\hline Sample Site codes & 1 & 2 & 3 & 4 & 5 & 6 & 7 \\
\hline $\mathrm{pH}$ & 7.23 & 7.68 & 7.44 & 7.59 & 7.43 & 7.47 & 7.40 \\
\hline Electrical Conductivity (EC) $\mu \mathrm{S} \mathrm{cm}^{-1}$ & 584.50 & 342.50 & 527.50 & 345.50 & 459.00 & 704.00 & 796.50 \\
\hline Total Dissolved Solid (TDS) $\mathrm{mg} \mathrm{l}^{-1}$ & 374.08 & 219.20 & 337.60 & 221.12 & 293.76 & 450.56 & 509.76 \\
\hline Turbidity NTU & 4.94 & $<0.01$ & 1.67 & 2.28 & $<0.01$ & $<0.01$ & 0.27 \\
\hline Calcium $\left(\mathrm{Ca}^{2+}\right) \mathrm{mg} \mathrm{l}^{-1}$ & 138.50 & 140.50 & 152.50 & 151.50 & 137.50 & 136.50 & 152.50 \\
\hline Magnesium $\left(\mathrm{Mg}^{2+}\right) \mathrm{mg} \mathrm{l}^{-1}$ & 61.30 & 67.75 & 75.55 & 63.30 & 68.30 & 82.30 & 92.15 \\
\hline Total Hardness as $\mathrm{CaCO}_{3} \mathrm{TH} \mathrm{mg}^{-1}$ & 598.21 & 629.76 & 680.40 & 650.34 & 625.15 & 679.67 & 760.17 \\
\hline Chloride $\left(\mathrm{Cl}^{-}\right) \mathrm{mg} \mathrm{l}^{-1}$ & 27.00 & 19.50 & 25.00 & 20.00 & 20.00 & 29.50 & 26.00 \\
\hline Sulphate $\left(\mathrm{SO}_{4}^{2-}\right) \mathrm{mg} \mathrm{l}^{-1}$ & 91.00 & 49.50 & 53.50 & 58.50 & 43.00 & 131.00 & 126.00 \\
\hline Phosphate $\left(\mathrm{PO}_{4}-\mathrm{P}\right) \mathrm{mg} \mathrm{l}^{-1}$ & 0.25 & 0.35 & 0.30 & 0.35 & 0.20 & 0.45 & 0.30 \\
\hline Sodium $\left(\mathrm{Na}^{+}\right) \mathrm{mg} \mathrm{l}^{-1}$ & 10.81 & 5.40 & 11.75 & 6.49 & 8.35 & 19.29 & 28.30 \\
\hline Potassium $\left(\mathrm{K}^{+}\right) \mathrm{mg} \mathrm{l}^{-1}$ & 0.37 & 0.43 & 0.28 & 0.33 & 0.20 & 2.26 & 1.78 \\
\hline Nitrate $\left(\mathrm{NO}_{3}-\mathrm{N}\right) \mathrm{mg}^{-1}$ & 8.50 & 3.70 & 4.50 & 6.90 & 6.25 & 1.50 & 4.60 \\
\hline Nitrite $\left(\mathrm{NO}_{2}-\mathrm{N}\right) \mathrm{mg} \mathrm{l}^{-1}$ & 0.02 & 0.01 & 0.02 & 0.01 & 0.02 & 0.01 & 0.02 \\
\hline
\end{tabular}


Table 3: Calculation of water quality index in site (1)

\begin{tabular}{|c|c|c|c|c|c|}
\hline Parameters & $\begin{array}{l}\text { Observed } \\
\text { Value }\left(\boldsymbol{V}_{\boldsymbol{n}}\right)\end{array}$ & $\begin{array}{c}\text { Standard } \\
\text { Value }\left(\boldsymbol{S}_{n}\right)\end{array}$ & $\begin{array}{l}\text { Unit weight } \\
(\boldsymbol{W n})\end{array}$ & $\begin{array}{l}\text { Quality rating } \\
\qquad\left(\boldsymbol{q}_{n}\right)\end{array}$ & $q_{n} W_{n}$ \\
\hline $\mathrm{pH}$ & 7.23 & $6.5-8.5$ & 0.1176 & 15.333 & 1.80 \\
\hline Electrical Conductivity (EC) $\mu \mathrm{S} \mathrm{cm}^{-1}$ & 584.50 & 1500 & 0.0007 & 38.9667 & 0.03 \\
\hline Total Dissolved Solid (TDS) $\mathrm{mg} \mathrm{l}^{-1}$ & 374.08 & 1000 & 0.0010 & 37.4080 & 0.04 \\
\hline Turbidity NTU & 4.94 & 5 & 0.2000 & 98.8000 & 19.76 \\
\hline Calcium $\left(\mathrm{Ca}^{2+}\right) \mathrm{mg} \mathrm{l}^{-1}$ & 138.50 & 75 & 0.0133 & 184.6667 & 2.46 \\
\hline Magnesium $\left(\mathrm{Mg}^{2+}\right) \mathrm{mg} \mathrm{l}^{-1}$ & 61.30 & 100 & 0.0100 & 61.3000 & 0.61 \\
\hline Total Hardness as $\mathrm{CaCO}_{3} \mathrm{TH} \mathrm{mg} \mathrm{l}^{-1}$ & 598.21 & 500 & 0.0020 & 119.6412 & 0.24 \\
\hline Chloride $\left(\mathrm{Cl}^{-}\right) \mathrm{mg} \mathrm{l}^{-1}$ & 27.00 & 250 & 0.0040 & 10.8000 & 0.04 \\
\hline Sulphate $\left(\mathrm{SO}_{4}{ }^{2-}\right) \mathrm{mg} \mathrm{l}^{-1}$ & 91.00 & 250 & 0.0040 & 36.4000 & 0.15 \\
\hline Phosphate $\left(\mathrm{PO}_{4}-\mathrm{P}\right) \mathrm{mg} \mathrm{l}^{-1}$ & 0.25 & 5 & 0.2000 & 5.0000 & 1.00 \\
\hline Sodium $\left(\mathrm{Na}^{+}\right) \mathrm{mg} \mathrm{l}^{-1}$ & 10.81 & 250 & 0.0040 & 4.3252 & 0.02 \\
\hline Potassium $\left(\mathrm{K}^{+}\right) \mathrm{mg} \mathrm{l}^{-1}$ & 0.37 & 12 & 0.0833 & 3.1000 & 0.26 \\
\hline Nitrate $\left(\mathrm{NO}_{3}-\mathrm{N}\right) \mathrm{mg}^{-1}$ & 8.50 & 10 & 0.1000 & 85.0000 & 8.50 \\
\hline Nitrite $\left(\mathrm{NO}_{2}-\mathrm{N}\right) \mathrm{mg} \mathrm{l}^{-1}$ & 0.02 & 3 & 0.3333 & 0.6667 & 0.22 \\
\hline & & & $\sum W n=\mathbf{1 . 0 7}$ & $\sum q_{n}=701.41$ & $\sum q_{n} W_{n}=\mathbf{3 5 . 1 2}$ \\
\hline
\end{tabular}

Table 4: Calculation of water quality index in site (2)

\begin{tabular}{|c|c|c|c|c|c|}
\hline Parameters & $\begin{array}{c}\text { Observed } \\
\text { Value }\left(\boldsymbol{V}_{n}\right)\end{array}$ & $\begin{array}{c}\text { Standard } \\
\text { Value }\left(\boldsymbol{S}_{n}\right)\end{array}$ & $\begin{array}{l}\text { Unit weight } \\
(\boldsymbol{W n})\end{array}$ & $\begin{array}{l}\text { Quality rating } \\
\qquad\left(\boldsymbol{q}_{n}\right)\end{array}$ & $q_{n} W_{n}$ \\
\hline $\mathrm{pH}$ & 7.68 & $6.5-8.5$ & 0.1176 & 45.3333 & 5.33 \\
\hline Electrical Conductivity (EC) $\mu \mathrm{S} \mathrm{cm}^{-1}$ & 342.50 & 1500 & 0.0007 & 22.8333 & 0.02 \\
\hline Total Dissolved Solid (TDS) $\mathrm{mg} \mathrm{l}^{-1}$ & 219.20 & 1000 & 0.0010 & 21.9200 & 0.02 \\
\hline Turbidity NTU & $<0.01$ & 5 & 0.2000 & 0.2000 & 0.04 \\
\hline Calcium $\left(\mathrm{Ca}^{2+}\right) \mathrm{mg} \mathrm{l}^{-1}$ & 140.50 & 75 & 0.0133 & 187.3333 & 2.49 \\
\hline Magnesium $\left(\mathrm{Mg}^{2+}\right) \mathrm{mg} \mathrm{l}^{-1}$ & 67.75 & 100 & 0.0100 & 67.7500 & 0.68 \\
\hline Total Hardness as $\mathrm{CaCO}_{3} \mathrm{TH} \mathrm{mg} \mathrm{l}^{-1}$ & 629.76 & 500 & 0.0020 & 125.9510 & 0.25 \\
\hline Chloride $\left(\mathrm{Cl}^{-}\right) \mathrm{mg} \mathrm{l}^{-1}$ & 19.50 & 250 & 0.0040 & 7.8000 & 0.03 \\
\hline Sulphate $\left(\mathrm{SO}_{4}{ }^{2-}\right) \mathrm{mg} \mathrm{l}^{-1}$ & 49.50 & 250 & 0.0040 & 19.8000 & 0.08 \\
\hline Phosphate $\left(\mathrm{PO}_{4}-\mathrm{P}\right) \mathrm{mg} \mathrm{l}^{-1}$ & 0.35 & 5 & 0.2000 & 7.0000 & 1.40 \\
\hline Sodium $\left(\mathrm{Na}^{+}\right) \mathrm{mg} \mathrm{l}^{-1}$ & 5.40 & 250 & 0.0040 & 2.1584 & 0.01 \\
\hline Potassium $\left(\mathrm{K}^{+}\right) \mathrm{mg} \mathrm{l}^{-1}$ & 0.43 & 12 & 0.0833 & 3.6167 & 0.30 \\
\hline Nitrate $\left(\mathrm{NO}_{3}-\mathrm{N}\right) \mathrm{mg}^{-1}$ & 3.70 & 10 & 0.1000 & 37.0000 & 3.70 \\
\hline Nitrite $\left(\mathrm{NO}_{2}-\mathrm{N}\right) \mathrm{mg} \mathrm{l}^{-1}$ & 0.01 & 3 & 0.3333 & 0.3333 & 0.11 \\
\hline & & & $\sum W n=1.07$ & $\sum q_{n}=549.03$ & $\sum q_{n} W_{n}=14.46$ \\
\hline
\end{tabular}

Table 5: Calculation of water quality index in site (3)

\begin{tabular}{|c|c|c|c|c|c|}
\hline Parameters & $\begin{array}{c}\text { Observed } \\
\text { Value }\left(\boldsymbol{V}_{\boldsymbol{n}}\right) \\
\end{array}$ & $\begin{array}{c}\text { Standard } \\
\text { Value }\left(\boldsymbol{S}_{\boldsymbol{n}}\right)\end{array}$ & $\begin{array}{l}\text { Unit weight } \\
(\boldsymbol{W n})\end{array}$ & $\begin{array}{l}\text { Quality rating } \\
\qquad\left(\boldsymbol{q}_{n}\right)\end{array}$ & $q_{n} W_{n}$ \\
\hline $\mathrm{pH}$ & 7.44 & $6.5-8.5$ & 0.1176 & 29.3333 & 3.45 \\
\hline Electrical Conductivity (EC) $\mu \mathrm{S} \mathrm{cm}^{-1}$ & 527.50 & 1500 & 0.0007 & 35.1667 & 0.02 \\
\hline Total Dissolved Solid (TDS) $\mathrm{mg} \mathrm{l}^{-1}$ & 337.60 & 1000 & 0.0010 & 33.7600 & 0.03 \\
\hline Turbidity NTU & 1.67 & 5 & 0.2000 & 33.4000 & 6.68 \\
\hline Calcium $\left(\mathrm{Ca}^{2+}\right) \mathrm{mg} \mathrm{l}^{-1}$ & 152.50 & 75 & 0.0133 & 203.3333 & 2.70 \\
\hline Magnesium $\left(\mathrm{Mg}^{2+}\right) \mathrm{mg} \mathrm{l}^{-1}$ & 75.55 & 100 & 0.0100 & 75.5500 & 0.76 \\
\hline Total Hardness as $\mathrm{CaCO}_{3} \mathrm{TH} \mathrm{mg} \mathrm{l}^{-1}$ & 680.40 & 500 & 0.0020 & 136.0796 & 0.27 \\
\hline Chloride $\left(\mathrm{Cl}^{-}\right) \mathrm{mg} \mathrm{l}^{-1}$ & 25.00 & 250 & 0.0040 & 10.0000 & 0.04 \\
\hline Sulphate $\left(\mathrm{SO}_{4}{ }^{2-}\right) \mathrm{mg} \mathrm{l}^{-1}$ & 53.50 & 250 & 0.0040 & 21.4000 & 0.09 \\
\hline Phosphate $\left(\mathrm{PO}_{4}-\mathrm{P}\right) \mathrm{mg} \mathrm{l}^{-1}$ & 0.30 & 5 & 0.2000 & 6.0000 & 1.20 \\
\hline Sodium $\left(\mathrm{Na}^{+}\right) \mathrm{mg} \mathrm{l}^{-1}$ & 11.75 & 250 & 0.0040 & 4.7016 & 0.02 \\
\hline Potassium $\left(\mathrm{K}^{+}\right) \mathrm{mg} \mathrm{l}^{-1}$ & 0.28 & 12 & 0.0833 & 2.3333 & 0.19 \\
\hline Nitrate $\left(\mathrm{NO}_{3}-\mathrm{N}\right) \mathrm{mg}^{-1}$ & 4.50 & 10 & 0.1000 & 45.0000 & 4.50 \\
\hline Nitrite $\left(\mathrm{NO}_{2}-\mathrm{N}\right) \mathrm{mg} \mathrm{l}^{-1}$ & 0.02 & 3 & 0.3333 & 0.6667 & 0.22 \\
\hline & & & $\sum W n=1.07$ & $\sum q_{n}=636.72$ & $\sum q_{n} W_{n}=\mathbf{2 0 . 1 8}$ \\
\hline
\end{tabular}


Table 6: Calculation of water quality index in site (4)

\begin{tabular}{|c|c|c|c|c|c|}
\hline Parameters & $\begin{array}{c}\text { Observed } \\
\text { Value }\left(\boldsymbol{V}_{n}\right) \\
\end{array}$ & $\begin{array}{c}\text { Standard } \\
\text { Value }\left(\boldsymbol{S}_{\boldsymbol{n}}\right)\end{array}$ & $\begin{array}{l}\text { Unit weight } \\
(\boldsymbol{W n})\end{array}$ & $\begin{array}{l}\text { Quality rating } \\
\left(\boldsymbol{q}_{n}\right)\end{array}$ & $q_{n} W_{n}$ \\
\hline $\mathrm{pH}$ & 7.59 & $6.5-8.5$ & 0.1176 & 39.3333 & 4.63 \\
\hline Electrical Conductivity (EC) $\mu \mathrm{S} \mathrm{cm}^{-1}$ & 345.50 & 1500 & 0.0007 & 23.0333 & 0.02 \\
\hline Total Dissolved Solid (TDS) $\mathrm{mg} \mathrm{l}^{-1}$ & 221.12 & 1000 & 0.0010 & 22.1120 & 0.02 \\
\hline Turbidity NTU & 2.28 & 5 & 0.2000 & 45.6000 & 9.12 \\
\hline Calcium $\left(\mathrm{Ca}^{2+}\right) \mathrm{mg} \mathrm{l}^{-1}$ & 151.50 & 75 & 0.0133 & 202.0000 & 2.69 \\
\hline Magnesium $\left(\mathrm{Mg}^{2+}\right) \mathrm{mg} \mathrm{l}^{-1}$ & 63.30 & 100 & 0.0100 & 63.3000 & 0.63 \\
\hline Total Hardness as $\mathrm{CaCO}_{3} \mathrm{TH}_{\mathrm{mg} \mathrm{l}}{ }^{-1}$ & 650.34 & 500 & 0.0020 & 130.0670 & 0.26 \\
\hline Chloride $\left(\mathrm{Cl}^{-}\right) \mathrm{mg} \mathrm{l}^{-1}$ & 20.00 & 250 & 0.0040 & 8.0000 & 0.03 \\
\hline Sulphate $\left(\mathrm{SO}_{4}{ }^{2-}\right) \mathrm{mg} \mathrm{l}^{-1}$ & 58.50 & 250 & 0.0040 & 23.4000 & 0.09 \\
\hline Phosphate $\left(\mathrm{PO}_{4}-\mathrm{P}\right) \mathrm{mg} \mathrm{l}^{-1}$ & 0.35 & 5 & 0.2000 & 7.0000 & 1.40 \\
\hline Sodium $\left(\mathrm{Na}^{+}\right) \mathrm{mg} \mathrm{l}^{-1}$ & 6.49 & 250 & 0.0040 & 2.5972 & 0.01 \\
\hline Potassium $\left(\mathrm{K}^{+}\right) \mathrm{mg} \mathrm{l}^{-1}$ & 0.33 & 12 & 0.0833 & 2.7500 & 0.23 \\
\hline Nitrate $\left(\mathrm{NO}_{3}-\mathrm{N}\right) \mathrm{mg}^{-1}$ & 6.90 & 10 & 0.1000 & 69.0000 & 6.90 \\
\hline Nitrite $\left(\mathrm{NO}_{2}-\mathrm{N}\right) \mathrm{mg} \mathrm{l}^{-1}$ & 0.01 & 3 & 0.3333 & 0.3333 & 0.11 \\
\hline & & & $\sum W n=\mathbf{1 . 0 7}$ & $\sum q_{n}=638.53$ & $\sum q_{n} W_{n}=\mathbf{2 6 . 1 4}$ \\
\hline
\end{tabular}

Table 7: Calculation of water quality index in site (5)

\begin{tabular}{|c|c|c|c|c|c|}
\hline Parameters & $\begin{array}{c}\text { Observed } \\
\text { Value }\left(\boldsymbol{V}_{\boldsymbol{n}}\right) \\
\end{array}$ & $\begin{array}{c}\text { Standard } \\
\text { Value }\left(\boldsymbol{S}_{n}\right) \\
\end{array}$ & $\begin{array}{c}\text { Unit weight } \\
(\boldsymbol{W n})\end{array}$ & $\begin{array}{l}\text { Quality rating } \\
\left(\boldsymbol{q}_{n}\right)\end{array}$ & $q_{n} W_{n}$ \\
\hline $\mathrm{pH}$ & 7.43 & $6.5-8.5$ & 0.1176 & 28.6667 & 3.37 \\
\hline Electrical Conductivity (EC) $\mu \mathrm{S} \mathrm{cm}^{-1}$ & 459.00 & 1500 & 0.0007 & 30.6000 & 0.02 \\
\hline Total Dissolved Solid (TDS) $\mathrm{mg} \mathrm{l}^{-1}$ & 293.76 & 1000 & 0.0010 & 29.3760 & 0.03 \\
\hline Turbidity NTU & $<0.01$ & 5 & 0.2000 & 0.2000 & 0.04 \\
\hline Calcium $\left(\mathrm{Ca}^{2+}\right) \mathrm{mg} \mathrm{l}^{-1}$ & 137.50 & 75 & 0.0133 & 183.3333 & 2.44 \\
\hline Magnesium $\left(\mathrm{Mg}^{2+}\right) \mathrm{mg} \mathrm{l}^{-1}$ & 68.30 & 100 & 0.0100 & 68.3000 & 0.68 \\
\hline Total Hardness as $\mathrm{CaCO}_{3} \mathrm{TH} \mathrm{mg} \mathrm{l}^{-1}$ & 625.15 & 500 & 0.0020 & 125.0292 & 0.25 \\
\hline Chloride $\left(\mathrm{Cl}^{-}\right) \mathrm{mg} \mathrm{l}^{-1}$ & 20.00 & 250 & 0.0040 & 8.0000 & 0.03 \\
\hline Sulphate $\left(\mathrm{SO}_{4}{ }^{2-}\right) \mathrm{mg} \mathrm{l}^{-1}$ & 43.00 & 250 & 0.0040 & 17.2000 & 0.07 \\
\hline Phosphate $\left(\mathrm{PO}_{4}-\mathrm{P}\right) \mathrm{mg} \mathrm{l}^{-1}$ & 0.20 & 5 & 0.2000 & 4.0000 & 0.80 \\
\hline Sodium $\left(\mathrm{Na}^{+}\right) \mathrm{mg} \mathrm{l}^{-1}$ & 8.35 & 250 & 0.0040 & 3.3404 & 0.01 \\
\hline Potassium $\left(\mathrm{K}^{+}\right) \mathrm{mg} \mathrm{l}^{-1}$ & 0.20 & 12 & 0.0833 & 1.6833 & 0.14 \\
\hline Nitrate $\left(\mathrm{NO}_{3}-\mathrm{N}\right) \mathrm{mg}^{-1}$ & 6.25 & 10 & 0.1000 & 62.5000 & 6.25 \\
\hline Nitrite $\left(\mathrm{NO}_{2}-\mathrm{N}\right) \mathrm{mg} \mathrm{l}^{-1}$ & 0.02 & 3 & 0.3333 & 0.6667 & 0.22 \\
\hline & & & $\sum W n=\mathbf{1 . 0 7}$ & $\sum q_{n}=562.90$ & $\sum q_{n} W_{n}=14.36$ \\
\hline
\end{tabular}

Table 8: Calculation of water quality index in site (6)

\begin{tabular}{|c|c|c|c|c|c|}
\hline Parameters & $\begin{array}{c}\text { Observed } \\
\text { Value }\left(\boldsymbol{V}_{\boldsymbol{n}}\right) \\
\end{array}$ & $\begin{array}{c}\text { Standard } \\
\text { Value }\left(\boldsymbol{S}_{\boldsymbol{n}}\right)\end{array}$ & $\begin{array}{l}\text { Unit weight } \\
(\boldsymbol{W n})\end{array}$ & $\begin{array}{l}\text { Quality rating } \\
\qquad\left(\boldsymbol{q}_{n}\right)\end{array}$ & $q_{n} W_{n}$ \\
\hline $\mathrm{pH}$ & 7.47 & $6.5-8.5$ & 0.1176 & 31.3333 & 3.68 \\
\hline Electrical Conductivity (EC) $\mu \mathrm{S} \mathrm{cm}^{-1}$ & 704.00 & 1500 & 0.0007 & 46.9333 & 0.03 \\
\hline Turbidity NTU & $<0.01$ & 5 & 0.2000 & 0.2000 & 0.04 \\
\hline Calcium $\left(\mathrm{Ca}^{2+}\right) \mathrm{mg} \mathrm{l}^{-1}$ & 136.50 & 75 & 0.0133 & 182.0000 & 2.42 \\
\hline Magnesium $\left(\mathrm{Mg}^{2+}\right) \mathrm{mg} \mathrm{l}^{-1}$ & 82.30 & 100 & 0.0100 & 82.3000 & 0.82 \\
\hline Chloride $\left(\mathrm{Cl}^{-}\right) \mathrm{mg} \mathrm{l}^{-1}$ & 29.50 & 250 & 0.0040 & 11.8000 & 0.05 \\
\hline Sulphate $\left(\mathrm{SO}_{4}{ }^{2-}\right) \mathrm{mg} \mathrm{l}^{-1}$ & 131.00 & 250 & 0.0040 & 52.4000 & 0.21 \\
\hline Phosphate $\left(\mathrm{PO}_{4}-\mathrm{P}\right) \mathrm{mg} \mathrm{l}^{-1}$ & 0.45 & 5 & 0.2000 & 9.0000 & 1.80 \\
\hline Sodium $\left(\mathrm{Na}^{+}\right) \mathrm{mg} \mathrm{l}^{-1}$ & 19.29 & 250 & 0.0040 & 7.7172 & 0.03 \\
\hline Potassium $\left(\mathrm{K}^{+}\right) \mathrm{mg} \mathrm{l}^{-1}$ & 2.26 & 12 & 0.0833 & 18.8250 & 1.57 \\
\hline Nitrate $\left(\mathrm{NO}_{3}-\mathrm{N}\right) \mathrm{mg}^{-1}$ & 1.50 & 10 & 0.1000 & 15.0000 & 1.50 \\
\hline
\end{tabular}




\begin{tabular}{|c|c|c|c|c|c|}
\hline Parameters & $\begin{array}{c}\text { Observed } \\
\text { Value }\left(\boldsymbol{V}_{\boldsymbol{n}}\right)\end{array}$ & $\begin{array}{c}\text { Standard } \\
\text { Value }\left(\boldsymbol{S}_{n}\right)\end{array}$ & $\begin{array}{l}\text { Unit weight } \\
(\boldsymbol{W n})\end{array}$ & $\begin{array}{l}\text { Quality rating } \\
\left(\boldsymbol{q}_{n}\right)\end{array}$ & $q_{n} W_{n}$ \\
\hline $\mathrm{pH}$ & 7.40 & $6.5-8.5$ & 0.1176 & 26.6667 & 3.14 \\
\hline Electrical Conductivity (EC) $\mu \mathrm{S} \mathrm{cm}^{-1}$ & 796.50 & 1500 & 0.0007 & 53.1000 & 0.04 \\
\hline Total Dissolved Solid (TDS) $\mathrm{mg} \mathrm{l}^{-1}$ & 509.76 & 1000 & 0.0010 & 50.9760 & 0.05 \\
\hline Turbidity NTU & 0.27 & 5 & 0.2000 & 5.4000 & 1.08 \\
\hline Calcium $\left(\mathrm{Ca}^{2+}\right) \mathrm{mg} \mathrm{l}^{-1}$ & 152.50 & 75 & 0.0133 & 203.3333 & 2.70 \\
\hline Magnesium $\left(\mathrm{Mg}^{2+}\right) \mathrm{mg} \mathrm{l}^{-1}$ & 92.15 & 100 & 0.0100 & 92.1500 & 0.92 \\
\hline Total Hardness as $\mathrm{CaCO}_{3} \mathrm{TH} \mathrm{mg} \mathrm{l}^{-1}$ & 760.17 & 500 & 0.0020 & 152.0348 & 0.30 \\
\hline Chloride $\left(\mathrm{Cl}^{-}\right) \mathrm{mg} \mathrm{l}^{-1}$ & 26.00 & 250 & 0.0040 & 10.4000 & 0.04 \\
\hline Sulphate $\left(\mathrm{SO}_{4}{ }^{2-}\right) \mathrm{mg} \mathrm{l}^{-1}$ & 126.00 & 250 & 0.0040 & 50.4000 & 0.20 \\
\hline Phosphate $\left(\mathrm{PO}_{4}-\mathrm{P}\right) \mathrm{mg} \mathrm{l}^{-1}$ & 0.30 & 5 & 0.2000 & 6.0000 & 1.20 \\
\hline Sodium $\left(\mathrm{Na}^{+}\right) \mathrm{mg} \mathrm{l}^{-1}$ & 28.30 & 250 & 0.0040 & 11.3196 & 0.05 \\
\hline Potassium $\left(\mathrm{K}^{+}\right) \mathrm{mg} \mathrm{l}^{-1}$ & 1.78 & 12 & 0.0833 & 14.8583 & 1.24 \\
\hline Nitrate $\left(\mathrm{NO}_{3}-\mathrm{N}\right) \mathrm{mg}^{-1}$ & 4.60 & 10 & 0.1000 & 46.0000 & 4.60 \\
\hline Nitrite $\left(\mathrm{NO}_{2}-\mathrm{N}\right) \mathrm{mg} \mathrm{l}^{-1}$ & 0.02 & 3 & 0.3333 & 0.6667 & 0.22 \\
\hline & & & $\Sigma W n=\mathbf{1 . 0 7}$ & $\sum q_{n}=723.31$ & $\sum q_{n} W_{n}=\mathbf{1 5 . 7 8}$ \\
\hline
\end{tabular}

\section{Conclusions}

The drinking water quality results of the villages Miradee, Ahmad brnda, China rah, Azaban, Siyara, Birke and Qashti, show that the highest water quality was recorded at the site $(1)$ Miradee $(\mathrm{WQI}=32.82)$ due to the increases in the human population, agricultural activities and it was very close to septic system, whereas the lowest quality found at site $(6)$ Birke $(\mathrm{WQI}=11.77)$. These water samples were fit for drinking without proper treatment according to standard WHO.

\section{Journal Papers}

\section{References}

[1] Yisa, J. and Jimoh, T., Analytical Studies on Water Quality Index of River Landzu. American Journal of Applied Sciences, 7(4), pp. 453-458, (2010).

[2] Panda, R.B. and Sinha, B.K., Investigation of water quality of Brahmani River. Indian Journal Environmental Health, 33(1), pp. 4549, (1991).

[3] Panigrahi, T.; Das, K.K.; Dey, B.S. and Panda, R.B., Assessment of Water Quality of river Sono, Balasore. International Journal Environmental Science, 3(1), pp. 49-56, (2012).

[4] Gebrehiwot, A.B.; Tadesse, N. and Jigar E., Food and Agriculture Science. ISABB Journal, 1(1), p.22, (2011).

[5] Kalavathy, S.; Rakesh Sharmas, R. and Sureshkumar P., Arch. Environmental Science, 5, 55, (2011).

[7] Kavitha, R. and Elangovan, K., Ground water quality characteristics at Erode district, Tamilnadu India. International Journal of Environmental Science, 1(2): pp. 145-150, (2010).

[8] Alobaidy, A. M.J.; Abid, H.S. and Maulood, B.H. Application of water quality index for assessment of Dokan lake ecosystem, Kurdistan region, Iraq. Journal of Water Resource and Protect, 2: pp. 792-798, (2010).

[9] Cude C., Oregon Water Quality Index: A tool for evaluating water quality management effectiveness, Journal of the American Water Resources Association, 37, 125137, (2001).

[10] Pandey, M. and Sundaram S.M., Trend of water quality of river Ganga at Varanasi using WQI approach, International Journal of Ecology and Environmental Science, 28, 139142, (2002).

[12] Alobaidy, A.M.; Abid, H.S. and Maulood, B.K., Application of water quality index for assessment of Dokan lake ecosystem, Kurdistan region, Iraqi Journal of Water Resource and Protection, (2), (2010). (http://www.SciRP.org/journal/jwarp).

[13] Khwakaram, A.I.; Majid, S.N. and Hama N.Y., determination of water quality index (WQI) for Qalyasan stream in Sulaimani city/Kurdistan region of Iraq. International Journal of Plant, Animal and Environmental Sciences. pp. 148-157, (2012).

[14] HamaSalh N.Y., Water Quality Index (Wqi) Of Some Wells Located In the Region of Kani Goma and Kanasura in Sulaimani Governorate. Journal of Zankoy Sulaimani, Part A (JZS-A), 16(1), pp. 15-29, (2014).

[20] Brown, R.M., McCleiland, N.J., Deininger, R.A. and O'Connor, M.F., A Water Quality Index - Crossing the Psychological Barrier (Jenkis, S.H., ed.) Proc. Int. Conf. on Water Poll. Res., Jerusalem, Vol.6, pp.787-797, (1972).

[21] Tripaty, J.K. and Sahu, K.C., Seasonal Hydrochemistry of Groundwater in the Barrier Spit System of the Chilika Lagoon, India. Journal of Environmental Hydrology, Vol.13, pp.1-9, (2005).

[23] Chaterjee, C. and Raziuddin, M., Determination of water quality index (WQI) of a degraded river in Asanol Industrial area, Raniganj, Burdwan, West Bengal. Nature, Environment and pollution Technology, 1(2): pp. 181-189, (2002).

[30] Egereonu, U.U. and Nwachukwu U.L., Evaluation of the surface and groundwater resources of Efuru River Catchment, Mbano, South Eastern, Nigeria. J. Assoc. Adv. Model. Simulat. Tech. Enterpr., 66: pp. 53-71, (2005).

\section{Books:}

[6] UNEP GEMS. Global drinking water quality index development and sensitivity analysis report. United Nations Environment Programme Global Environment Monitoring System/Water Programme. 58 p., (2007). (www.gemswater.org).

[15] APHA, AWWA and WEF, Standard Methods for the Examination of Water and Wastewater. $20^{\text {th }}$ Edn., APHA, Washington, DC, (1998).

[16] American Public Health Association (A.P.H.A.). Standard methods for the examination of water and waste water. $17^{\text {th }}$ Ed. A. P. H. A., Washington, (1989).

[17] Jackson, M. L., Soil Chemical Analysis. Prentice Hall. Inc. London. (Cited from P. C. Jaiswal, 2003), (1958).

[18] Wilcox, L. V., Electrical Conductivity. Amer. Water Works Assoc. Journal. 42:p.775-776. (Cited from P, C. Jaiswal, 2003), (1950).

[19] WHO, "Guideline for drinking water quality', $4^{\text {th }}$ edition, World Health Organization, Geneva, (2011). 
[24] WHO, Guidelines for Drinking-water Quality. Third Edition Volume 1: Recommendations. World Health Organisation, Geneva, (2004).

[25] Boyd, C.E., "Water Quality an Introduction". Kluwer Acadamic Publi-shers, Boston, USA, 330P, (2000).

[27] WHO, Guidelines for Drinking Water Quality .2nd .Ed. Vol.2. World Health Organization, Geneva, (1996).

[31] Chapman, D.V., Water Quality Assessment-A Guide to Use Biota, Sediment and Water in Environmental Monitoring. 2nd Edn., ISBN: 041921590, p. 626, (1996).

\section{Chapters in Books:}

[22] Sinha, A.K., Saxena, S. and Saxena, R., Water quality index for Ram Ganga river water at Moradabad. Pollution Research, 23, pp. $527-531,(2004)$

Thesis:

[11] Shekha, Y.A. The effect of Erbil city wastewater discharge on water quality quality of Greater Zab river,and the risk of irrigation. Thesis PhD. Baghdad University, (2008).

[26] Rasheed, R. O., A limnological study on some water system in Arbil province. M.Sci. Thesis, Univ. of Salahaddin, Iraq, (1994).

[29] Ganjo, D. G. A., an Ecological study on Ruwandiz river path within Erbil province, Iraq.Ph.D. Thesis, Univ. of Salahaddin-Hawler, Iraq, (1997).

[28] Zeywayee, F. A. Q., phycolimnological study on some springs and streams within Erbil province. M.Sc. Thesis Salahaddin Univ., Erbil, Iraq, (2011). 